\title{
A nanotechnology-foresight perspective of South Africa
}

\author{
Brian Masara $\mathbb{D} \cdot$ John Andrew van der Poll • Malik Maaza
}

Received: 23 July 2020 / Accepted: 21 March 2021 / Published online: 13 April 2021

(C) The Author(s), under exclusive licence to Springer Nature B.V. 2021

\begin{abstract}
This paper presents a foresight perspective of nanotechnology in South Africa based on a 20-year period scientometric analysis of the country's nanotechnology publications on the Web of Science (WoS) Core Collection. Firstly, publication trends are reported; then, possible socio-economic relevant sectors arising from this information are determined. Lastly, indicators that can be used in foresight exercises to
\end{abstract}

This article is part of the topical collection on Nanotechnology Convergence in Africa

Guest Editors: Mamadou Diallo, Abdessattar Abdelkefi, and Bhekie Mamba

B. Masara · M. Maaza

UNESCO-UNISA Africa Chair in Nanoscience and Nanotechnology (U2ACN2), College of Graduate Studies, University of South Africa, Muckleneuk Ridge, PO Box 392, Pretoria, South Africa

B. Masara · M. Maaza $(\bowtie)$

Nanosciences African Network (NANOAFNET), iThemba LABS-National Research Foundation, 1 Old Faure Road, PO Box 722, Somerset West, Western Cape 7129, South Africa e-mail: Maaza@tlabs.ac.za

B. Masara · J. A. van der Poll

UNISA, Graduate School of Business Leadership (SBL), Midrand, University of South Africa, Muckleneuk Ridge, PO Box 392, Pretoria, South Africa

B. Masara $(\bowtie)$

South African Institute of Physics, Postnet Suite 165, Private Bag X025, Lynnwood Ridge, Pretoria, South Africa

e-mail: brian.masara@saip.org.za evaluate the potential nanotechnology research areas in South Africa are examined. The 20-year review is also compared with the recent past year, 2019, to identify any changing trends. South Africa's nanotechnology publications per year grew exponentially from 68 papers in 2000 to 1672 in 2019 , an increase of $2459 \%$. The total share of nanotech publications increased from $1.4 \%$ in 2000 to $6.6 \%$ in 2019 , thus a $0.52 \%$ increase per year. Compared with Brazil, Russia, India and China, the BRICS countries, South Africa has the lowest nanotechnology productivity with an activity index of 0.68 . Over the last 5 years, South Africa nanotech publications had a Hirschindex of 94 and an average citations rate of 12.76 per paper. Universities are the most prominent publishers, and there are very few publications from the private sector, which can negatively impact the commercialisation of nanotechnology research. The top 10 most prolific researchers, author or co-author over $20 \%$ of the nanotechnology papers are reported. A mixture of old and new top researchers' names suggests succession planning in the system as the years progress. The emergence of computer science as one of the top 20 subjects publishing in nanotech in 2019 and a high level of researcher collaboration suggests possible convergence of nanotech, information technology and artificial intelligence in South Africa. The strategic socioeconomic-focused nanotechnology research areas identified for South Africa include material science, photoluminance and optics, medicine, catalysis, electronics, energy, biotech, magnetism, sensors, water and communicable diseases. The top collaborating countries, top researchers, top institutions and nanotechnology 
economic hubs are reported for each strategic research area. The level of innovation was evaluated using the nanotechnology value chain, and there is a meagre 3.5\% of papers reporting on nano-enabled products.

Keywords Technology foresight · Nanotechnology Scientometrics · Tech-mining · Innovation .

Nanotechnology value chain

\section{Introduction}

Scientific innovations create value by developing new products and services, providing solutions to social problems, creating new enterprises and jobs, thereby improving the quality of life. Nanotechnology is an extremely disruptive emerging field of science dedicated to the study and manipulation of characteristics of matter at the atomic level, where the onset of size-dependent phenomena usually enables novel applications (Karpagam et al. 2011; Robinson et al. 2007; Salerno et al. 2008). Discoveries from nanoscience have a vast range of socio-economic benefits and significantly contribute to humanity's achieving the Sustainable Development Goals (SDGs). For example, discoveries from nanotechnology are providing solutions for affordable clean water (Mamba et al. 2007; Mwabi et al. 2011), efficient solar cells for renewable energy (Banin et al. 2020) and medical solutions, for example, nano-assisted face masks in destroying COVID-19 pathogens (De Sio et al. 2021). In addition, because of its multidisciplinary and interdisciplinary nature, plus the use of nanoscale building blocks (atoms and molecules), nanotechnology has become the core for the convergence of several disciplines (Roco and Bainbridge 2002; Salerno et al. 2008);

From a business and economic perspective, nanotechnology-enabled commercial products are increasing at an exponential rate (Islam and Miyazaki 2009), such that by 2013, the nano-enabled product's market was already over US\$1 trillion (NSF 2014) and expected to reach US\$3 trillion while contributing 6 million jobs by 2020 (Roco 2017). Hence, various scholars argue that nanotechnology will underpin the next Schumpeterian wave of world economic development (Linton and Walsh 2008; Mangematin and Walsh 2012; Tuncel 2015). As a result, many governments worldwide have positioned themselves to benefit from nanotechnology by implementing national nanotechnology initiatives. Countries that have implemented national nanotech strategies include the United States of America (USA), United Kingdom (UK), Japan, India, South Korea, Germany and South Africa, among others (Ali and Sinha 2014; Grassian et al. 2016; Miyazaki and Islam 2007; Roco et al. 2011).

Nanotechnology is a broad general purpose technology with applications in any field imaginable. To ensure limited resources are prudently utilised, countries or businesses cannot invest in nanotech across the board, but they have to select and focus on critical strategic nanotech research areas that possess the most significant potential to bring socio-economic development, competitiveness and return on investment (Connell et al. 2001; Lee and Song 2007; Shen et al. 2010). Hence, foresight methodologies must be utilised to identify key research areas to focus on and concentrate on (Salerno et al. 2008). Technology foresight is defined as the process of systematically considering the longer-term future of science, technology, economy and society to identify the key strategic research areas and those emerging generic technologies with the highest potential to result in socio-economic development (Martin 1995). Hence, technology foresight exercises must form an integral part of any research and development strategic plan to help identify critical technologies and $\mathrm{R} \& \mathrm{D}$ areas with the highest potential to support socioeconomic development (Firat et al. 2008).

\section{Technology foresight versus technology forecasting}

The terms technology foresight and technology forecasting are sometimes used intangibility and to mean the same contextual principal and construct; this is evident when scholars define these terms, list their drivers, goals and methods that can be used to accomplish both. However, (Martin 2001) contends that scholars must note that foresight is different from technology forecasting. He argues that technology forecasting assumes that there is one unique future. Thus, in technology forecasting, the planner should predict future technology as accurate as possible. However, in technology foresight, one assumes that there are numerous possibilities for the future, and future technologies depend on planning choices. This research, therefore, uses the term technology foresight.

\section{Foresight epistemology}

There are two broad epistemological approaches to foresight studies, the positivism and interpretive approaches. 
The positivism or realist epistemology of foresight argues that knowledge of the future is based on analysis of the past and present, which is then extrapolated into the future. It is in this school of thought that quantitative methods of foresight are based, for example, methods such as scanning the environment using publications in scientometrics, statistical techniques and extrapolation to estimate the future. Under this argument, Von Wright (2009) proposed the Laplace's Demon, a hypothetical observer which, based on its perfect knowledge, could predict the exact future state of the world (Von Wright 2009). However, Kalle and Rafael (Kalle and Rafael 2015) argue that predicting the future based on knowledge of past and present is probabilistic and uncertain at best because one can never be sure that the structure of the world does not change within the period of interest; thus, one can only estimate the future subject to limitations that follow from the assumptions for the extrapolation (Kalle and Rafael 2015).

The other school of thought in foresight studies is that given by Hideg (Hideg 2007) as quoted in (Kalle and Rafael 2015), who state that, “... the future is interpreted as something that already exists in the present in the thoughts and emotions of people. ... Future thoughts are forming and reforming in the process of discourses, so the futures existing in the present are open and humanly constructed". Hence, Kalle and Rafael (2015) argue that the future already exists in the thoughts and emotions of people. It is from this school of thought that the qualitative approaches to foresight are based. Thus, one can use various forms of interviews like expert interviews and Delphi, brainstorming, creative workshops, wild cards, among others in trying to understand ideas and images of the future already existing in people's minds to gain knowledge about the future.

\section{Scientometrics and technology foresight}

Scientometrics is the study of the quantitative aspects of science utilising scientific documents such as academic journal publications, patents and policies (Jacobs 2010; Leydesdorff and Milojevic 2012). Scientometrics is traditionally utilised in Research Development and Innovation Evaluation Studies and to compare individual researchers, institutions or country performance among other evaluations. Several researchers have used scientometric studies to study the state of nanotechnology research in different countries (Hullman and Meyer 2003; Islam and Miyazaki
2010; Karpagam et al. 2011; Marinova and McAleer 2002; Tanaka 2013). Scientometrics was previously used to study the state of nanotechnology research in South Africa (Makhoba and Pouris 2017; Pouris 2007). However, this research used a different publications search strategy, covers a period of 20 years and focuses on nanotechnology foresight perspective.

Scientometrics can also be used as a foresight tool. The justification for the use of scientometrics in foresight studies is that publications data is an intermediate measure of innovation because science innovations start from basic science research (where publications are produced) that feeds the applied sciences and technological disciplines. Scientometrics use scientific publications data to capture innovation, research and development activities closer to basic science research, while patent data highlight activities closer to the commercialisation stage. The nanotechnology value chain can also be used to evaluate the state of maturity of nanotechnology research systems.

The advantage of scientometrics use in foresight studies was given by Lee (2008) and Santo et al. (2006) (de Miranda et al. 2006) who note that one of the most critical aspects of scientometrics analysis is that it goes beyond the experts' biases, enabling the discovery of facts and trends not perceived due to the limit of knowledge or prejudiced visions of experts. However, the use of scientometrics in foresight studies is very low, and this is supported by empirical evidence from research done by Popper (2008), where it was observed that out of 886 foresight studies done worldwide, scientometrics (bibliometrics) use constituted only 2.4\% (Popper 2008). Also, no nanotechnology foresight research has been published since the establishment of the South Africa nanotechnology strategy. Thus, there is a need to improve and add to the literature on the use of scientometrics in technology foresight method and the nanotechnology foresight for South Africa.

In this study, the positivism, empirical and realist epistemology of foresight is followed because there are many publications on nanotechnology that can be analysed to study the past, the present, estimate the trends and extrapolate into the future. Thus, scientometric analysis was used to give a foresight perspective of the South African nanotechnology research landscape.

\section{Methodology}

Scientometric analysis was carried out through techmining utilising the Vantage Point Software. Tech- 
mining is the application of text mining tools to science and technology structured databases informed by technological innovation processes to produce Science Technology and Innovation (STI) indicators for decision making. Tech-mining uses the power of computers to analyse all documents (patents and publications) that are found in an area under investigation as compared with experts who are forced to sample a few publications to give a summary (Mikova and Sokolova 2014; Porter and Cunningham 2005).

A 20-year scientometric analysis of South African nanotechnology publications was done using data obtained from the Web of Science Core Collection. Porter et al. (2008) developed a modularised Boolean approach to defining nanotechnology, and the strategy was further refined by Arora et al. (2013). This search strategy was adapted and utilised to search and retrieve nanotechnology publications for analysis. Publications from 2000 to 2019 were analysed. The year 2000 was chosen as the starting period because that is when nanopublications began an exponential growth (Islam and Miyazaki 2009).

Vantage Point software does both basic and advanced scientometric functions that help elicit relationships among data fields such as authors, research fields, topics about which they write, their organisations, citations, collaborations, time series analysis among others (Porter and Cunningham 2005). Data analysis followed three logical steps. Step 1 involved clustering records into nanotechnology research areas, thus determining possible key research areas. Step 2 involved tabulating the size-dependent indicators of each research area, for example, counting the number of publications per research field and finally calculating normalised size-independent scientometric indicators for each research field.

\section{Validity and reliability}

The following precautions were taken to ensure the validity and reliability of the tech-mining results of this research. First, a well-established Boolean nanotechnology search strategy (Porter et al. 2008) was adapted to extract target records for analysis from the Web of Science core collection. Also, data cleaning was carried out to validate that the search strategy yielded high recall while balancing precision in extracting the nanotechnology-specific records for analysis.
Secondly, a large sample of papers, 11,265, was analysed, thereby reducing sampling error. Sampling error is more prevalent where the sample of objects being measured is very small; in this case, the sample used was substantial.

\section{Results and discussion}

This study aimed to use tech-mining to develop a foresight perspective of nanotechnology in South Africa using nanotechnology publications over the last 20 years, from 2000 to 2019 .

The first step in foresight is scanning the research environment and understanding the major science and technology developments, including the major research area and alternatives. The second step of the foresight process is identifying key stakeholders who can be consulted in developing the identified research area for South Africa. The third step of foresight is the generation phase, where identified research areas are evaluated and analysed, and favourable futures that can support socio-economic development are identified. The above three steps of foresight are reported below.

\section{Nanotechnology publications trend in South Africa}

Table 1 below summarises South Africa's nanotechnology publication trend between 2000 and 2019. Publications per year increased from 68 in 2000 to 1672 in 2019 , which is an increase of $2458 \%$. The country's total publications, on the other hand, increased from 4950 in 2000 to 25,163 in 2019 , which is an increase of $508 \%$. Thus, nanotechnology research publications grew at a faster rate than other areas, and this relative growth is further explained by Fig. 1 below.

Figure 1 above shows that the total share of nanotechnology publications increased from $1.4 \%$ in 2000 to $6.6 \%$ in 2019 , thus a $0.52 \%$ increase per year.

South Africa nanotechnology output in comparison with BRICS countries

The world's five major emerging economies, namely Brazil, Russia, India, China, and South Africa, form a grouping named the BRICS. South Africa's performance in nanotechnology was compared with that of BRICS countries using the nanotechnology activity index. The activity index (AI) is defined as the ratio of the 
Table 1 South Africa's nanotechnology publications relative to total publications on WoS

\begin{tabular}{lllll}
\hline Year & $\begin{array}{l}\text { Nanotech } \\
\text { publications }\end{array}$ & $\begin{array}{l}\text { Total } \\
\text { publications }\end{array}$ & $\begin{array}{l}\text { Nanotech } \\
\text { share } \%\end{array}$ & $\begin{array}{l}\text { Annual } \\
\text { nanotech } \\
\text { growth } \%\end{array}$ \\
\hline 2000 & 68 & 4950 & $1.4 \%$ & \\
2001 & 83 & 4979 & $1.7 \%$ & $22 \%$ \\
2002 & 84 & 5384 & $1.6 \%$ & $1 \%$ \\
2003 & 96 & 5156 & $1.9 \%$ & $14 \%$ \\
2004 & 135 & 5767 & $2.3 \%$ & $41 \%$ \\
2005 & 163 & 6062 & $2.7 \%$ & $21 \%$ \\
2006 & 170 & 6955 & $2.4 \%$ & $4 \%$ \\
2007 & 245 & 8138 & $3.0 \%$ & $44 \%$ \\
2008 & 276 & 8931 & $3.1 \%$ & $13 \%$ \\
2009 & 337 & 9881 & $3.4 \%$ & $22 \%$ \\
2010 & 417 & 10,218 & $4.1 \%$ & $24 \%$ \\
2011 & 476 & 11,686 & $4.1 \%$ & $14 \%$ \\
2012 & 628 & 13,652 & $4.6 \%$ & $32 \%$ \\
2013 & 726 & 14,104 & $5.1 \%$ & $16 \%$ \\
2014 & 830 & 15,422 & $5.4 \%$ & $14 \%$ \\
2015 & 983 & 20,044 & $4.9 \%$ & $18 \%$ \\
2016 & 1199 & 21,982 & $5.5 \%$ & $22 \%$ \\
2017 & 1289 & 22,946 & $5.6 \%$ & $8 \%$ \\
2018 & 1388 & 23,782 & $5.8 \%$ & $8 \%$ \\
2019 & 1672 & 25,163 & $6.6 \%$ & $20 \%$ \\
Total & 11,265 & 245,202 & & \\
\hline & & & & \\
\hline
\end{tabular}

country's share in the publication output in the field to the country's share in the world's publication outputs in all fields (Rousseau 2018). The world activity index is considered to be one (1); hence, the AI for country X over period $\mathrm{P}$ can be approximated by equation (1) below.

$\mathrm{AI}($ nano, country $\mathrm{X})=$

$$
\frac{\text { Country } \mathrm{X} \text { ratio of nanopublications in period } \mathrm{P}}{\text { World ratio of nanopublications in period } \mathrm{P}}
$$

Table 2 shows the comparison of South Africa to BRICS countries for 20 years as well as a 1-year snapshot. The results indicate that over the 20 -year period from 2000 to 2019, South Africa had the lowest productivity in nanotechnology with an activity index of 0.68. China, with an activity index of 2 , is the most productive country among the BRICS countries. However, when a single year (2019) is considered, the picture is almost the same South Africa was second from the bottom with an AI of 0.78. China and India remained at the top in terms of country activity index. From a foresight perspective, it means South Africa can benefit from collaborating with the more productive BRICS countries, benchmark and understand how South Africa can also improve to achieve comparable nanotechnology activity levels.

Nanotechnology publishing institutions in South Africa

Analysis of South Africa's most active nanotechnology research publishers is shown in Table 3 below. The results show that the majority of publishers are universities.

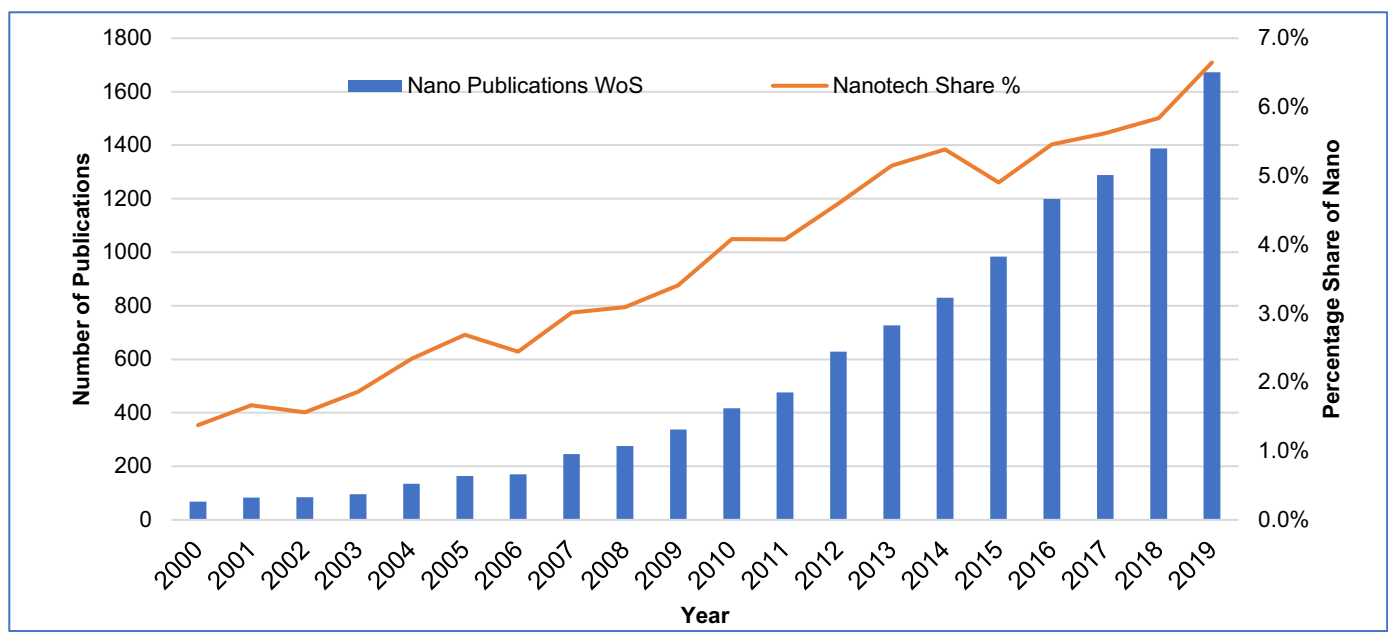

Fig. 1 Nanotechnology publication trend for South Africa 
Table 2 SA nanotechnology publications compared with BRICS countries

\begin{tabular}{|c|c|c|c|c|c|c|c|c|c|}
\hline \multicolumn{5}{|c|}{ 20-year period 2000-2019 } & \multicolumn{5}{|c|}{ 1-year period 2019} \\
\hline Country & $\begin{array}{l}\text { Nano } \\
\text { publications }\end{array}$ & Total WoS & Nano ratio & $\begin{array}{l}\text { Activity } \\
\text { index }\end{array}$ & Country & $\begin{array}{l}\text { Nano } \\
\text { publications }\end{array}$ & Total WoS & Nano ratio & Activity index \\
\hline World & $2,718,619$ & $40,331,494$ & 0.067 & 1.00 & World & 260,675 & $3,168,362$ & 0.082 & 1.00 \\
\hline China & 664,787 & $4,939,513$ & 0.135 & 2.00 & China & 94,059 & 607,574 & 0.155 & 1.88 \\
\hline India & 165,351 & $1,312,591$ & 0.126 & 1.87 & India & 22,399 & 140,491 & 0.159 & 1.94 \\
\hline Russia & 93,394 & 876,138 & 0.107 & 1.58 & Russia & 9447 & 91,764 & 0.103 & 1.25 \\
\hline Brazil & 45,656 & 874,857 & 0.052 & 0.77 & Brazil & 5211 & 87,818 & 0.059 & 0.72 \\
\hline South Africa & 11,264 & 245,202 & 0.046 & 0.68 & South Africa & 1672 & 26,190 & 0.064 & 0.78 \\
\hline
\end{tabular}

Table 3 Major nanotechnology publication contributors in South Africa

\begin{tabular}{|c|c|c|c|c|c|}
\hline \multicolumn{3}{|l|}{ 20-year period 2000-2019 } & \multicolumn{3}{|l|}{ 1-year period 2019} \\
\hline Institutions & Publications & Share \% & Institutions & Publications & Share $\%$ \\
\hline 1) South Africa & 11264 & $100 \%$ & South Africa & 1672 & $100 \%$ \\
\hline 2) University of Johannesburg & 1583 & $14 \%$ & University of Johannesburg & 355 & $21 \%$ \\
\hline 3) University of Witwatersrand & 1370 & $12 \%$ & University of KwaZulu Natal & 242 & $14 \%$ \\
\hline 4) University of KwaZulu Natal & 1286 & $11 \%$ & University of South Africa & 202 & $12 \%$ \\
\hline $\begin{array}{l}\text { 5) Council Scientific \& Industrial } \\
\text { Research (CSIR) }\end{array}$ & 1044 & $9 \%$ & $\begin{array}{l}\text { National Research } \\
\text { Foundation (iThembaLABS) }\end{array}$ & 165 & $10 \%$ \\
\hline 6) University of Pretoria & 959 & $9 \%$ & University of Witwatersrand & 152 & $9 \%$ \\
\hline 7) University of Free State & 940 & $8 \%$ & University of Pretoria & 134 & $8 \%$ \\
\hline 8) University of Stellenbosch & 905 & $8 \%$ & University of The Free State & 129 & $8 \%$ \\
\hline 9) University of South Africa & 867 & $8 \%$ & Tshwane University of Technology & 118 & $7 \%$ \\
\hline $\begin{array}{l}\text { 10) National Research Foundation } \\
\text { (iThembaLABS) }\end{array}$ & 789 & $7 \%$ & $\begin{array}{l}\text { Council Scientific \& Industrial } \\
\text { Research (CSIR) }\end{array}$ & 116 & $7 \%$ \\
\hline 11) University of Cape Town & 748 & $7 \%$ & University of the Western Cape & 105 & $6 \%$ \\
\hline 12) Rhodes University & 665 & $6 \%$ & North West University South Africa & 92 & $6 \%$ \\
\hline 13) University of the Western Cape & 642 & $6 \%$ & University of Stellenbosch & 80 & $5 \%$ \\
\hline 14) Tshwane University of Technology & 494 & $4 \%$ & University of Cape Town & 79 & $5 \%$ \\
\hline 15) North West University & 492 & $4 \%$ & Rhodes University & 62 & $4 \%$ \\
\hline 16) Nelson Mandela University & 327 & $3 \%$ & Durban University of Technology & 56 & $3 \%$ \\
\hline 17) University of Zululand & 260 & $2 \%$ & Nelson Mandela University & 55 & $3 \%$ \\
\hline 18) Durban University of Technology & 206 & $2 \%$ & University of Zululand & 42 & $3 \%$ \\
\hline 19) Vaal University of Technology & 174 & $2 \%$ & Vaal University of Technology & 33 & $2 \%$ \\
\hline 20) University of Fort Hare & 142 & $1 \%$ & University of Fort Hare & 31 & $2 \%$ \\
\hline $\begin{array}{l}\text { 21) Cape Peninsula University of } \\
\text { Technology }\end{array}$ & 121 & $1 \%$ & University of Limpopo & 19 & $1 \%$ \\
\hline 22) MINTEK & 87 & $1 \%$ & University of Venda & 17 & $1 \%$ \\
\hline 23) University of Limpopo & 82 & $1 \%$ & $\begin{array}{l}\text { Cape Peninsula University of } \\
\text { Technology }\end{array}$ & 16 & $1 \%$ \\
\hline 24) University of Venda & 75 & $1 \%$ & $\begin{array}{l}\text { Sefako Makgatho Health Sciences } \\
\text { University }\end{array}$ & 11 & $1 \%$ \\
\hline 25) SASOL Technology & 24 & $0.21 \%$ & $\begin{array}{l}\text { National Institute of } \\
\text { Theoretical Physics (NITheP) }\end{array}$ & 11 & $1 \%$ \\
\hline
\end{tabular}


Over a 20-year analysis period, the most prolific publisher is the University of Johannesburg, contributing $14 \%$, followed by the University of the Witwatersrand with $12 \%$ and in third place is the University of KwaZulu Natal with $11 \%$. The second group of publishers are national research facilities comprising only three institutions, namely the Council for Scientific and Industrial Research (CSIR), iThembaLABS, and MINTEK. The CSIR is the most prolific national facility in the fourth position, producing $9 \%$ of the publications, iThembaLABS and MINTEK had $7 \%$ and $1 \%$ of nanotechnology publications, respectively.

Only a single private company, SASOL-technology, was identified with 24 publications, a $0.21 \%$ contribution to the total output. This observation shows a lack of participation of the private sector in nanotechnology research, and from a foresight perspective, this will impact the innovation and commercialisation of nanotechnology research. This suggests a need to engage more private sector companies to be involved in nanotechnology research from a foresight planning perspective.

When the 1-year snapshot is considered, the top publishers over 20 years remained mostly unchanged. The University of South Africa, iThembaLABS and Tshwane University of Technology show that they have increased their nanotechnology activity. However, during the same period, the WITS university changed from 3rd to 6th position, and the CSIR went down from 5th position to 10th position.

Five-year Hirsch-index of South Africa nanotechnology publications

A key scientometric indicator obtained from publication analysis is the Hirsch-index (H-index) used to quantify a scientist's published research impact (Hirsch 2005). The $\mathrm{H}$-index discounts for the disproportionate weight of highly cited publications and papers not yet cited. The H-index is determined from the list of an individual/institution's publications ranked in descending order by the number of times cited. H-index is equal to the number of papers $(N)$ in the list that has $N$ or more citations. The $\mathrm{H}$-index or its modified version, the 5-year H-index denoted H5-index, is now used as a de facto tool for assessing individual researchers, universities, research institutions and even journals (Karpagam et al. 2011).

In order to evaluate the immediate impact of nanotechnology publications from South African institutions, the 5-year Hirsch-index (H5-index) was evaluated for the top ten publishing institutions in the last 5 years (2015-2019). Over the last 5 years, South Africa nanotechnology publications have a combined H5-index of 94 and an average citations rate of 12.76 per paper. During the same period, the top ten publishing institutions produced papers with an $\mathrm{H} 5$-index in the range 58 to 32 . The average citation was 16.17 to 10.46 , as shown in Table 4 below.

Researchers publishing in South Africa

Table 5 below shows the top ten researchers in terms of papers they either authored or co-authored for nanotechnology publications for South Africa. According to data on the WoS core collection between 2000 and 2019, there was a total of 30614 authors/co-authors who wrote the 11,265 nanotechnology-related publications. However, the top ten researchers shown below together contributed $21.35 \%$ of publications. When the single year 2019 is considered, the result shows the top 10 researchers also contributed $20.39 \%$ of total publications. This result is inline Lotka's law (Phillips 2013) which state that the distributions of science and technology publications is highly skewed such that the leaders tend to be extremely prolific, while the rest occur in "ones and twos."

The single-year snapshot shows that the top 4 authors remained the same people. However, there are new names coming top in the 1-year, 2019 analysis. The emergence of new top authors suggested that new

Table 4 H5-index for top ten South Africa nanotechnology publishing institutions 2015-2019

\begin{tabular}{lll}
\hline Institutions & H5-index & $\begin{array}{l}\text { Average citations } \\
\text { per item }\end{array}$ \\
\hline South Africa & 94 & 12.76 \\
1. University of Johannesburg & 58 & 16.17 \\
2. University of South Africa & 55 & 14.54 \\
3. National Research Foundation & 45 & 15.55 \\
$\quad$ iThemba Labs) & & \\
4. Council Scientific \& Industrial & 44 & 14.88 \\
$\quad$ Research (CSIR) & & 10.89 \\
5. University of KwaZulu Natal & 43 & 11.21 \\
6. University of Witwatersrand & 40 & 15.92 \\
7. University of Cape Town & 39 & 11.66 \\
8. University of Pretoria & 38 & 13.22 \\
9. University of Stellenbosch & 34 & 10.46 \\
10. University of Free State & 32 & \\
\hline
\end{tabular}


Table 5 Top ten researchers (authors/co-author) for nanotechnology publications in South Africa

\begin{tabular}{|c|c|c|c|c|c|}
\hline \multicolumn{3}{|l|}{ 20-year period 2000-2019 } & \multicolumn{3}{|l|}{ 1-year period 2019} \\
\hline Researcher name & Number of publications & Share $\%$ & Researcher name & Number of publications & Share $\%$ \\
\hline 1) NYOKONG T & 445 & $3.95 \%$ & 1) MAAZA M & 56 & $3.35 \%$ \\
\hline 2) SWART HC & 388 & $3.44 \%$ & 2) SWART HC & 45 & $2.69 \%$ \\
\hline 3) MAAZA M & 326 & $2.89 \%$ & 3) NYOKONG T & 39 & $2.33 \%$ \\
\hline 4) RAY SS & 260 & $2.31 \%$ & 4) RAY SS & 34 & $2.03 \%$ \\
\hline 5) GUPTA VK & 178 & $1.58 \%$ & 5) VAN DER BRUGGEN B & 34 & $2.03 \%$ \\
\hline 6) COVILLE NJ & 172 & $1.53 \%$ & 6) OLUBAMBI PA & 33 & $1.97 \%$ \\
\hline 7) NTWAEABORWA OM & 167 & $1.48 \%$ & 7) KAVIYARASU K & 27 & $1.61 \%$ \\
\hline 8) REVAPRASADU N & 166 & $1.47 \%$ & 8) EZEMA FI & 26 & $1.56 \%$ \\
\hline 9) MAMBA BB & 153 & $1.36 \%$ & 9) DEJENE FB & 25 & $1.50 \%$ \\
\hline 10) EBENSO EE & 151 & $1.34 \%$ & 10) MAMBA BB & 22 & $1.32 \%$ \\
\hline Total percentage contribution & & $21.35 \%$ & Total percentage contribution & & $20.39 \%$ \\
\hline
\end{tabular}

researchers/authors are coming into the system mixed with experienced authors who have been there for years. This mixture is essential in foresight planning because it demonstrates continuity, and it suggests some form of succession planning taking place within the nanotechnology system of South Africa.

South Africa international collaboration in nanotechnology

International collaboration was analysed from coauthorship between South Africa and other countries. Figure 2 shows the top 20 countries collaborating with South Africa. In the last 20 years, India was the largest collaborating partner for South Africa with 1241 (11\%) publications, and the USA comes second with 919 (8.2\%) publications. On the African continent, Nigeria is South Africa's largest collaborating partner with 585 (5.2\%) publications.

When one considers just the year 2019, India remains the biggest collaborating partner for South Africa. However, in 2019, Nigeria was number 2, and another African country Botswana comes up in the top 20 collaborating countries at number 16 , suggesting increasing inter Africa-collaboration in nanotechnology. Another observation is that the percentage of collaboration between South Africa and the BRICS countries increased in 2019 compared with the last 20 years. For example, in 2019 , Russia now appears on the top 20 at number 17 , but it did not appear on the top 20 for the last 20 years; this can be attributed to efforts made under the BRICS collaboration.

Subject area focus for nanotechnology in South Africa

The examination of subject areas was carried out using the subject area classification of Web of Science. Table 6 below shows the top 20 subject areas in which nanotechnology research is published in South Africa. The most prolific subject area is chemistry accounting for over $34 \%$. The top four subject areas, namely chemistry, material science, physics and engineering, together account for $93.05 \%$ in the last 20 years and $95.34 \%$ in 2019 .

When the 1-year snapshot is considered, one finds that computer science, which did not appear on the top 20 subjects, now appears on the list contributing $1.26 \%$ of publications in 2019 . The emergence of computer science as one of the top 20 subjects publishing in nanotechnology suggests a convergence of nanotechnology and computing science, for example, in areas such as artificial intelligence (AI) system design and the drive towards the 4th Industrial Revolution (4IR). Nanotechnology publications from computer science can also be a sign of nanotechnology convergence (Roco 2020). However, additional investigations need to be done to ascertain the existence and extent of the fusion of nanotechnology, biotechnology, information technology, and cognitive sciences (NBIC) in South Africa. 


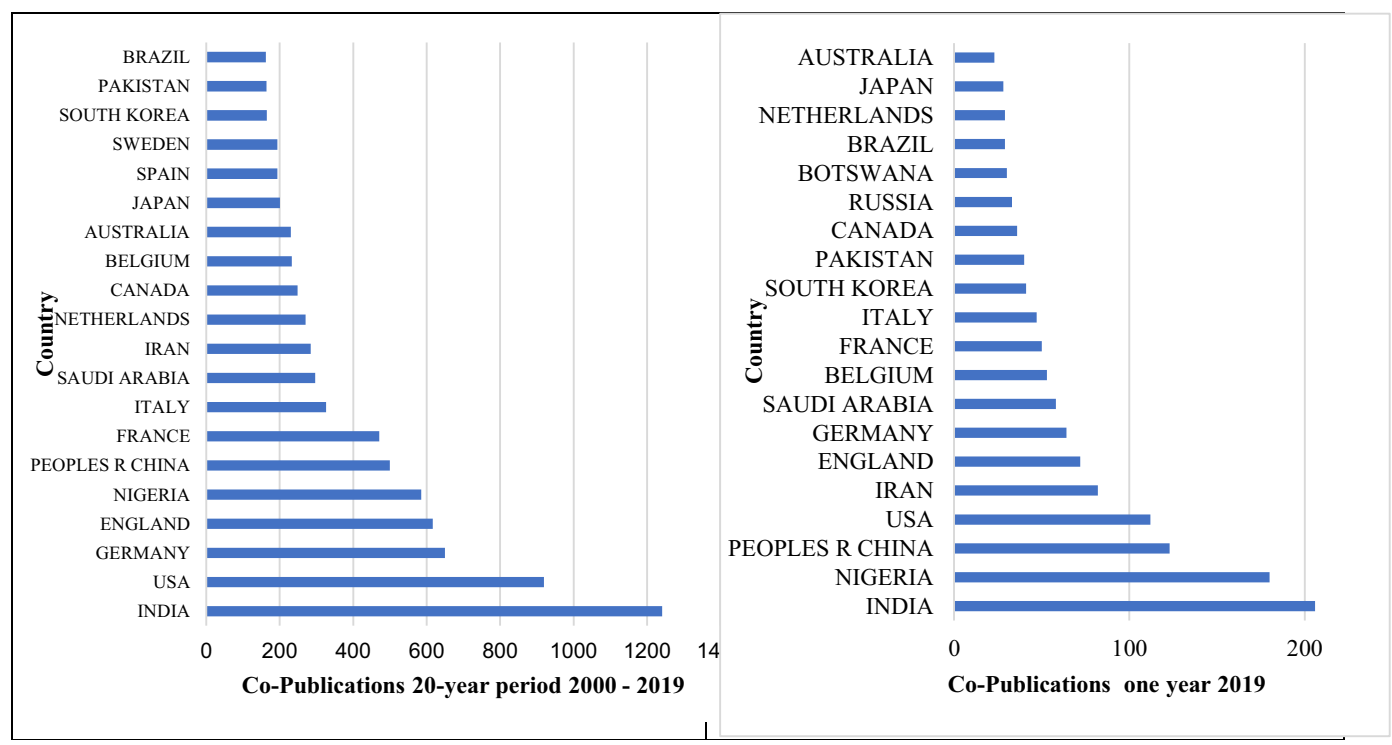

Fig. 2 Countries collaborating with South Africa in nanotechnology

Table 6 Top subject areas in which South Africa nanotechnology papers are published

\begin{tabular}{|c|c|c|c|c|c|}
\hline \multicolumn{3}{|l|}{ 20-year period 2000-2019 } & \multicolumn{3}{|l|}{ 1-year period 2019} \\
\hline Subject area & Publications & Share $\%$ & Subject area & Publications & Share $\%$ \\
\hline 1) Chemistry & 3832 & 34.02 & Chemistry & 577 & 34.51 \\
\hline 2) Materials Science & 2733 & 24.26 & Materials Science & 434 & 25.96 \\
\hline 3) Physics & 2558 & 22.71 & Physics & 316 & 18.90 \\
\hline 4) Engineering & 1358 & 12.06 & Engineering & 308 & 18.42 \\
\hline 5) Science Technology Other Topics & 1259 & 11.18 & Science Technology Other Topics & 252 & 15.07 \\
\hline 6) Electrochemistry & 637 & 5.66 & Electrochemistry & 80 & 4.78 \\
\hline 7) Polymer science & 610 & 5.42 & Environmental Sciences Ecology & 75 & 4.49 \\
\hline 8) Biochemistry Molecular Biology & 464 & 4.12 & Polymer Science & 71 & 4.25 \\
\hline 9) Optics & 355 & 3.15 & Energy Fuels & 62 & 3.71 \\
\hline 10) Environmental Sciences Ecology & 354 & 3.14 & Biochemistry Molecular Biology & 59 & 3.53 \\
\hline 11) Pharmacology Pharmacy & 324 & 2.88 & Pharmacology Pharmacy & 59 & 3.53 \\
\hline 12) Energy Fuels & 291 & 2.58 & Optics & 46 & 2.75 \\
\hline 13) Crystallography & 277 & 2.46 & Metallurgy Metallurgical Engineering & 44 & 2.63 \\
\hline 14) Metallurgy Metallurgical Engineering & 253 & 2.25 & Biotechnology Applied Microbiology & 27 & 1.61 \\
\hline 15) Biotechnology Applied Microbiology & 216 & 1.92 & Instruments Instrumentation & 27 & 1.61 \\
\hline 16) Water Resources & 169 & 1.50 & Thermodynamics & 27 & 1.61 \\
\hline 17) Instruments Instrumentation & 161 & 1.43 & Mechanics & 25 & 1.50 \\
\hline 18) Thermodynamics & 145 & 1.29 & Water Resources & 23 & 1.38 \\
\hline 19) Genetics Heredity & 143 & 1.27 & Crystallography & 22 & 1.32 \\
\hline 20) Biophysics & 137 & 1.22 & Computer Science & 21 & 1.26 \\
\hline
\end{tabular}


South Africa foresight research areas analysis

Technology foresight is the process of systematically considering the longer-term future of science, technology, economy and society to identify the key strategic research areas with the highest potential to result in socio-economic development (Martin 1995). Possible foresight research areas were generated from the analysis of South Africa's National Development Plan (NDP) Vision for 2030 (NPC 2011), the 10-Year National Innovation Plan (DST 2007) and the Nanotechnology Strategy 2005 (DST 2005). Combining these government policy requirements and nanotechnology subfields found in literature, the following possible socioeconomic relevant research areas were identified, food, agriculture, automotive, cosmetics, mining, material science, energy, medicine, communicable diseases, electronics, photoluminance and optics, water, nanotools, sensors, catalysis, magnetism, biotechnology, nanofibers, nanofluids, textiles and engineering applications.

To identify if the above-mentioned research areas exist in the South African nanotechnology publications, one has to classify and categorise related research together. Unfortunately, as an emerging research area, the system of classifying nanotech research papers is not yet well established, there is no readily available lookup database for nanoscience research areas categorisation (Tanaka 2013). Tanaka (2013) proposed a system, but it is not comprehensive; it just gives basic science disciplines as categories, for example, nanophysics, nanochemistry and nanoengineering which is almost similar to WoS subject categorisation. An automatic nanotechnology publication categorising protocol was developed in Vantage Point utilising the thesaurus function and relevant keywords for each research area. This protocol was used to automatically group the South Africa publications into the foresight research area categories identified above. The system uses a oneto-many mapping such that a paper can fit into more than one research area, for example, a paper in energy discussing photovoltaics can at times fit into electronics and a biotechnology paper can at times also fit into medicine and communicable diseases.

Strategic foresight-based research areas

Table 7 below shows that for the last 20 years, the top research areas for South Africa's nanoscience were in
Nanomaterials (25\%), Photoluminance and Optics $(19 \%)$ and Nano-Medicine (18\%). Nanoscience research on water and communicable diseases only make up $3 \%$ and $2 \%$, respectively. When a 1 -year snapshot of the research areas is considered, one finds that there is no significant difference in the top research areas. However, in 2019, engineering applications of nanotechnology now come up the radar contributing $2 \%$ of publications in 2019.

The rest of the possible foresight research areas proposed above, such as food, textiles and automotive applications, had small ratios below $0.05 \%$; hence, they will not be considered in this analysis.

South Africa research area experts

An essential step in any foresight process is mobilising and engaging key stakeholders who can be consulted in developing the identified research areas for South Africa. Table 8 below gives a summary of the top 10 nanotechnology experts against their number of publications per research area. The top publishing researcher per field has their number of publications highlighted by bold text; for example, the top publisher in Materials is Ray Suprakas; in medicine, it is Nyokong Tebello; while in electronics and energy, it is Maaza Malik; in water, it is Mamba Bhekie; in photoluminance and optics, it is Swart Hendrik. Nanotechnology foresight planners can use Table 8 to assemble a team of experts per field for further consultations.

South Africa research area institutions specialisations

In foresight, institutions are also part of the key stakeholders required in developing any selected research area. Table 9 shows the top publishing institution per research area. The most prolific publishing organisation is highlighted in bold text. For example, foresight planners can see that the top institutions for nanomedicine are the University of KwaZulu Natal, University of Witwatersrand and University of Cape Town. Alternately, they can also note that University of the Free state is the leading publisher in photoluminance and optics, and the University of Pretoria is the leading institution for nanoelectronics. 
Table 7 Top research areas for South Africa

\begin{tabular}{|c|c|c|c|c|c|}
\hline \multicolumn{3}{|l|}{ 20-year period 2000-2019 } & \multicolumn{3}{|l|}{ 1-year period 2019} \\
\hline Nanotechnology research area & Number of publications & Ratio & Nanotechnology research area & Number of publications & Ratio \\
\hline 1) Materials & 2845 & $25 \%$ & 1) Materials & 415 & $25 \%$ \\
\hline 2) Photoluminance \& Optics & 2172 & $19 \%$ & 2) Photoluminance \& Optics & 367 & $22 \%$ \\
\hline 3) Medicine & 2008 & $18 \%$ & 3) Medicine & 329 & $20 \%$ \\
\hline 4) Catalysis & 1606 & $14 \%$ & 4) Catalysis & 287 & $17 \%$ \\
\hline 5) Electronics & 1390 & $12 \%$ & 5) Electronics & 237 & $14 \%$ \\
\hline 6) Biotech & 1021 & $9 \%$ & 6) Biotech & 194 & $12 \%$ \\
\hline 7) Energy & 655 & $6 \%$ & 7) Energy & 135 & $8 \%$ \\
\hline 8) Magnetism & 587 & $5 \%$ & 8) Sensors & 102 & $6 \%$ \\
\hline 9) Sensors & 553 & $5 \%$ & 9) Magnetism & 99 & $6 \%$ \\
\hline 10) Water & 328 & $3 \%$ & 10) Water & 79 & $5 \%$ \\
\hline 11) Communicable Diseases & 243 & $2 \%$ & 11) Engineering Applications & 38 & $2 \%$ \\
\hline
\end{tabular}

South Africa research area international collaborators

International collaboration analysis is essential during foresight planning. Table 10 shows the top collaborating countries per research area using the number of papers the country co-authored with South Africa in the respective research area. The top collaborating countries per field are highlighted in bold text. India features as the top collaborating country in seven research areas; however, for medicine and communicable diseases, the top collaborating country is the USA, for energy China, and, for water Belgium.

South Africa nanotechnology research-clusters

A distinguishing feature of $R \& D$ activities is their agglomeration to specific regions rather than being evenly distributed within countries. This view is supported by Porter and Stern (2001), who argue that the physical location of $R \& D$ facilities is a significant factor that

Table 8 Top Ten South African nanoscience researchers in the identified research areas

\begin{tabular}{|c|c|c|c|c|c|c|c|c|c|c|}
\hline \multirow{2}{*}{$\begin{array}{l}\text { South Africa } \\
\text { Research Area }\end{array}$} & \multicolumn{10}{|c|}{ Researcher name } \\
\hline & $\begin{array}{l}\text { Nyokong. } \\
\text { Tebello }\end{array}$ & $\begin{array}{l}\text { Maaza. } \\
\text { Malik }\end{array}$ & $\begin{array}{l}\text { Swart. } \\
\text { Hendrik } \\
\text { C }\end{array}$ & $\begin{array}{l}\text { Gupta. } \\
\text { Vinod } \\
\text { Kumar }\end{array}$ & $\begin{array}{l}\text { Ray. } \\
\text { Suprakas } \\
\text { Sinha }\end{array}$ & $\begin{array}{l}\text { Kasinathan. } \\
\text { Kaviyarasu }\end{array}$ & $\begin{array}{l}\text { Agarwal. } \\
\text { Shilpi }\end{array}$ & $\begin{array}{l}\text { Ntwaeaborwa. } \\
\text { Odireleng M }\end{array}$ & $\begin{array}{l}\text { Covill. } \\
\text { Neville } \\
\text { J }\end{array}$ & $\begin{array}{l}\text { Mamba. } \\
\text { Bhekie } \\
\text { Brilliance }\end{array}$ \\
\hline Materials & 107 & 116 & 55 & 68 & 150 & 31 & 30 & 17 & 47 & 71 \\
\hline $\begin{array}{l}\text { Photoluminance } \\
\text { \& Optics }\end{array}$ & 87 & 185 & 309 & 25 & 47 & 56 & 13 & 149 & 15 & 13 \\
\hline Medicine & 98 & 48 & 17 & 25 & 29 & 27 & 17 & 9 & 2 & 12 \\
\hline Catalysis & 123 & 39 & 14 & 53 & 35 & 36 & 25 & 3 & 67 & 43 \\
\hline Electronics & 30 & 60 & 26 & 4 & 27 & 9 & 3 & 8 & 21 & 11 \\
\hline Biotech & 35 & 23 & 6 & 13 & 11 & 14 & 6 & 0 & 0 & 8 \\
\hline Energy & 23 & 45 & 16 & 1 & 6 & 11 & 0 & 8 & 6 & 2 \\
\hline Magnetism & 41 & 19 & 8 & 7 & 34 & 3 & 6 & 3 & 17 & 10 \\
\hline Sensors & 20 & 18 & 11 & 19 & 7 & 7 & 7 & 4 & 7 & 10 \\
\hline Water & 1 & 0 & 1 & 18 & 12 & 0 & 7 & 0 & 0 & 36 \\
\hline
\end{tabular}

The top publishing researcher per research area is highlighted in bold text 


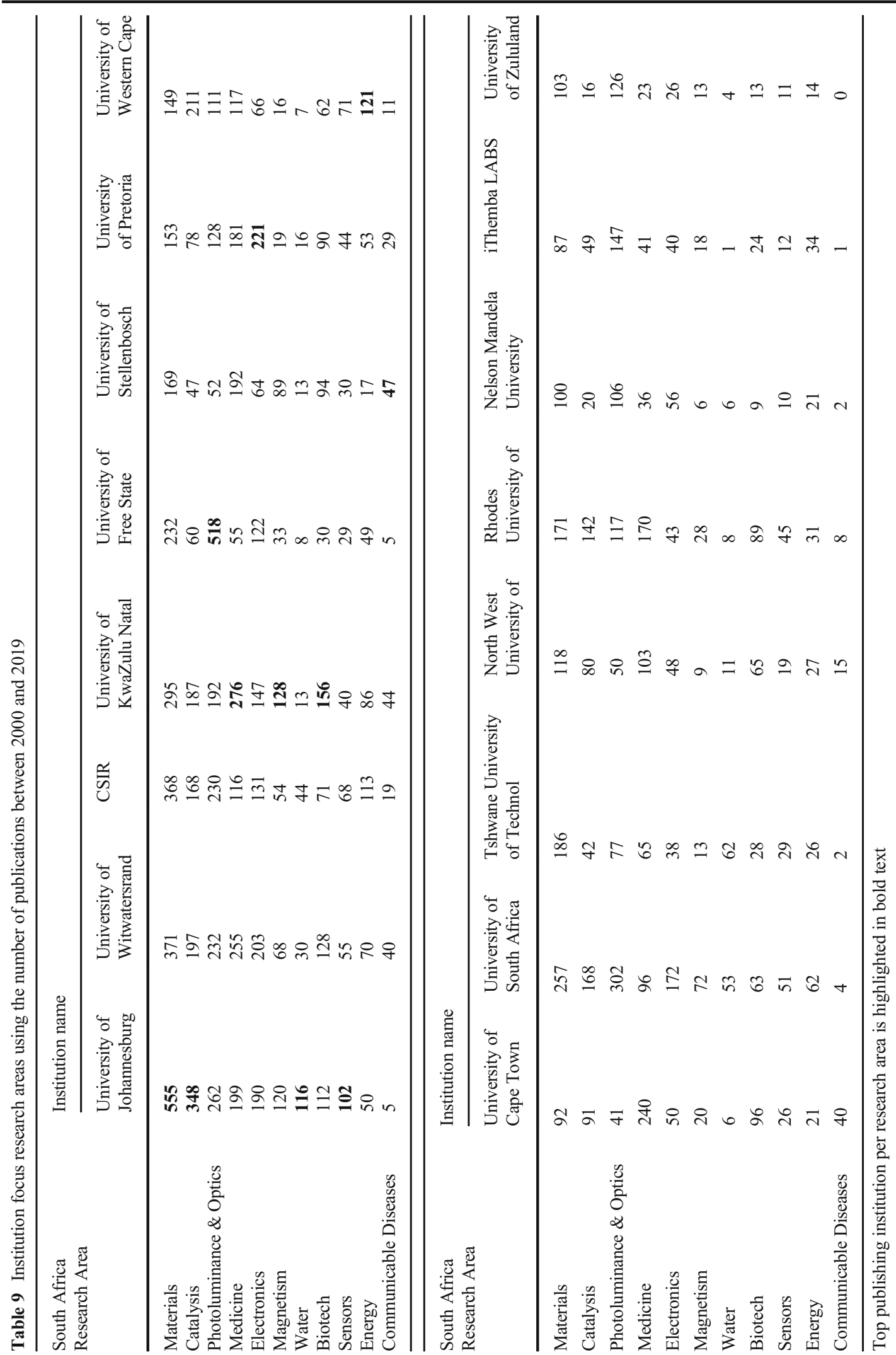


Table 10 Collaborating-country focus research areas using number of publications between 2000 and 2019

\begin{tabular}{|c|c|c|c|c|c|c|c|c|c|c|c|}
\hline Area & India & USA & UK & China & Germany & Nigeria & France & Iran & Saudi Arabia & Italy & Belgium \\
\hline Photoluminance \& Optics & 363 & 114 & 139 & 67 & 94 & 143 & 98 & 32 & 48 & 69 & 17 \\
\hline Materials & 323 & 119 & 106 & 68 & 106 & 208 & 75 & 73 & 76 & 54 & 36 \\
\hline Catalysis & 200 & 54 & 56 & 142 & 47 & 63 & 34 & 48 & 52 & 17 & 14 \\
\hline Medicine & 193 & 290 & 170 & 62 & 129 & 70 & 95 & 37 & 56 & 47 & 52 \\
\hline Electronics & 136 & 82 & 85 & 52 & 94 & 92 & 40 & 19 & 47 & 48 & 13 \\
\hline Magnetism & 116 & 23 & 27 & 28 & 44 & 17 & 20 & 22 & 26 & 21 & 6 \\
\hline Biotech & 111 & 103 & 71 & 30 & 44 & 41 & 25 & 21 & 24 & 19 & 15 \\
\hline Sensors & 78 & 31 & 30 & 29 & 25 & 21 & 33 & 27 & 18 & 12 & 18 \\
\hline Energy & 43 & 27 & 49 & 87 & 35 & 31 & 16 & 3 & 8 & 14 & 7 \\
\hline Water & 30 & 33 & 14 & 28 & 5 & 17 & 2 & 22 & 11 & 2 & 43 \\
\hline Communicable Diseases & 22 & 77 & 41 & 5 & 17 & 3 & 14 & 1 & 6 & 6 & 15 \\
\hline
\end{tabular}

The top collaborating country per research area is highlighted in bold text

contributes to successful innovations. Certain areas present a competitive advantage in R\&D innovations and commercialisation (Porter and Stern 2001). In economics, the geographic agglomeration of economic activity results in the improved technological or economic performance of the units involved (Peneder 1997). The economic benefits of technological agglomeration result from three major forces which are (1) knowledge spillovers between firms, e.g. sharing tacit knowledge; (2) local availability of specialised inputs and services from supporting industries; and (3) a geographically pooled labour market for specialised skills (Marshal 1920).
Also, geographical proximity/clustering reduces operational costs for units involved (Fiedler and Welpe 2011).

In foresight planning, one needs to understand nanotechnology research clusters, including their research focus to be able to derive future innovation and commercialisation benefits linked to such clusters. A clustering system for nanotechnology institutions in South Africa was done using the country's main economic hubs and provinces. Table 11 shows the number of publications per research areas according to South Africa's nanotechnology research clusters. The top two clusters for a particular research area are

Table 11 South Africa nanotechnology clusters and research area focus 2000-2019

\begin{tabular}{|l|c|c|c|c|c|c|c|c|}
\hline Area & Pretoria & Johannesburg & $\begin{array}{c}\text { Western } \\
\text { Cape }\end{array}$ & Free State & $\begin{array}{c}\text { KwaZulu } \\
\text { Natal }\end{array}$ & $\begin{array}{c}\text { North } \\
\text { West }\end{array}$ & $\begin{array}{c}\text { Eastern } \\
\text { Cape }\end{array}$ & \begin{tabular}{c} 
Limpopo \\
\hline Materials
\end{tabular} \\
\hline $\begin{array}{l}\text { Photoluminance } \\
\text { \& Optics }\end{array}$ & $\mathbf{6 9 2}$ & $\mathbf{8 9 6}$ & 571 & 242 & 452 & 145 & 237 & 38 \\
\hline Medicine & 414 & 483 & 447 & 519 & 322 & 65 & 202 & 14 \\
\hline Catalysis & 394 & $\mathbf{5 3 7}$ & 440 & 104 & 221 & 105 & 135 & 22 \\
\hline Electronics & $\mathbf{5 0 4}$ & 374 & 312 & 126 & 184 & 56 & 89 & 9 \\
\hline Biotech & 225 & 240 & $\mathbf{3 0 1}$ & 30 & 202 & 73 & 90 & 24 \\
\hline Energy & $\mathbf{2 2 4}$ & 116 & 209 & 50 & 102 & 36 & 46 & 24 \\
\hline Magnetism & 135 & 174 & $\mathbf{1 8 2}$ & 38 & 145 & 12 & 32 & 8 \\
\hline Sensors & $\mathbf{1 6 3}$ & $\mathbf{1 6 3}$ & 160 & 30 & 67 & 22 & 50 & 13 \\
\hline Water & $\mathbf{1 5 0}$ & 140 & 45 & 10 & 30 & 12 & 12 & 11 \\
\hline $\begin{array}{l}\text { Communicable } \\
\text { Diseases }\end{array}$ & 46 & 47 & $\mathbf{1 0 1}$ & 5 & 51 & 15 & 10 & 3 \\
\hline
\end{tabular}

The top two research clusters per research area are highlighted in yellow

The top cluster per research area is highlighted in bold text 


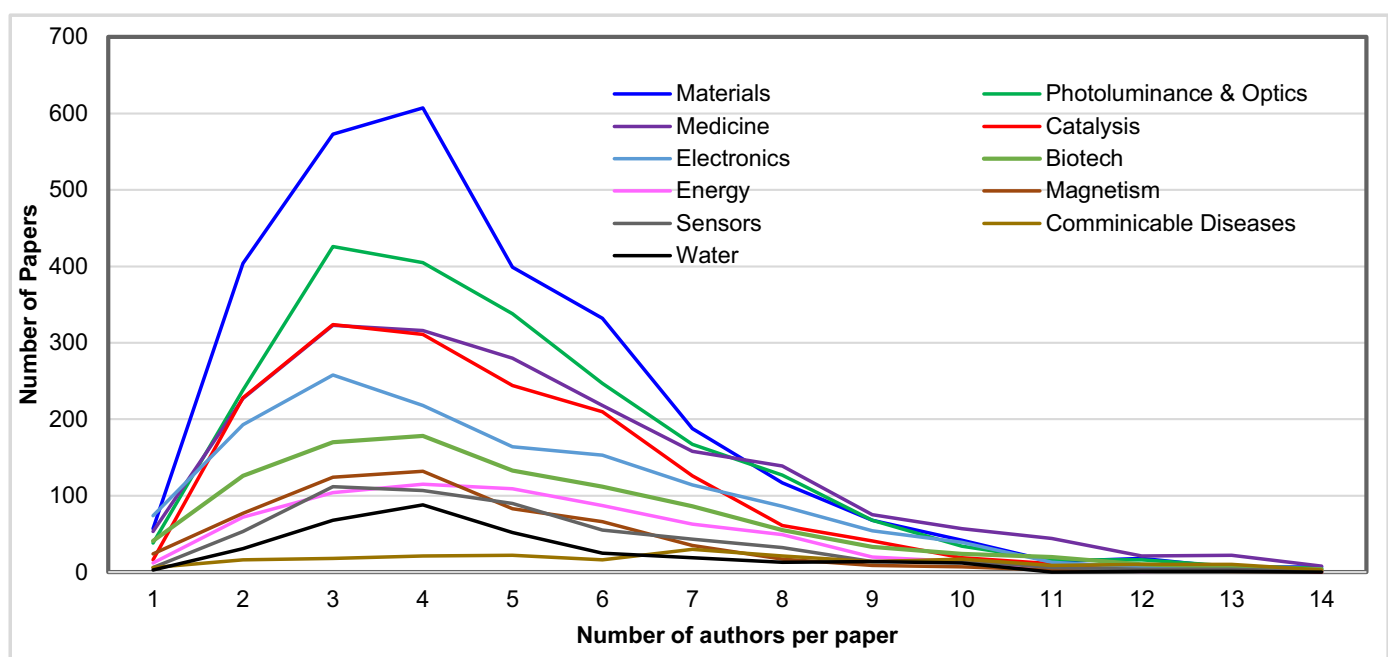

Fig. 3 Level of researcher collaboration per research area

highlighted and the most prolific cluster in bold text. Table 11 shows that if one needs to develop in photoluminance and optics, they need to locate either in Pretoria, or the Free State; for nanomedicine, they need be in the Western Cape or Johannesburg, and communicable diseases research in the Western Cape or KwaZulu Natal region.

\section{South Africa research areas degree of collaboration}

Cross-functional or interdisciplinary teams are viewed as one of the critical success factors for technological innovation (Connell et al. 2001; Torkkeli and Tuominen 2001). Interdisciplinarity in nanoscale research is one major thrust of science policymakers (Schummer 2004); for example, the USA Nanotechnology policy (Battard
2012) and the South Africa nanotechnology policy (DST 2005) both advocate for more interdisciplinary collaborations in nanotechnology research.

The extent or degree of collaboration can be measured by applying Subramanyam's formula (Subramanyam 1983), which states that the degree of collaboration $C$ is a ratio between the number of multiauthored papers (NM) to the number of multi-authored papers (NM) plus the single authored (NS) ones as given in equation (2) below.

$$
C=\frac{N M}{N M+N S}
$$

where

- $\mathrm{NM}=$ number of multi-authored papers

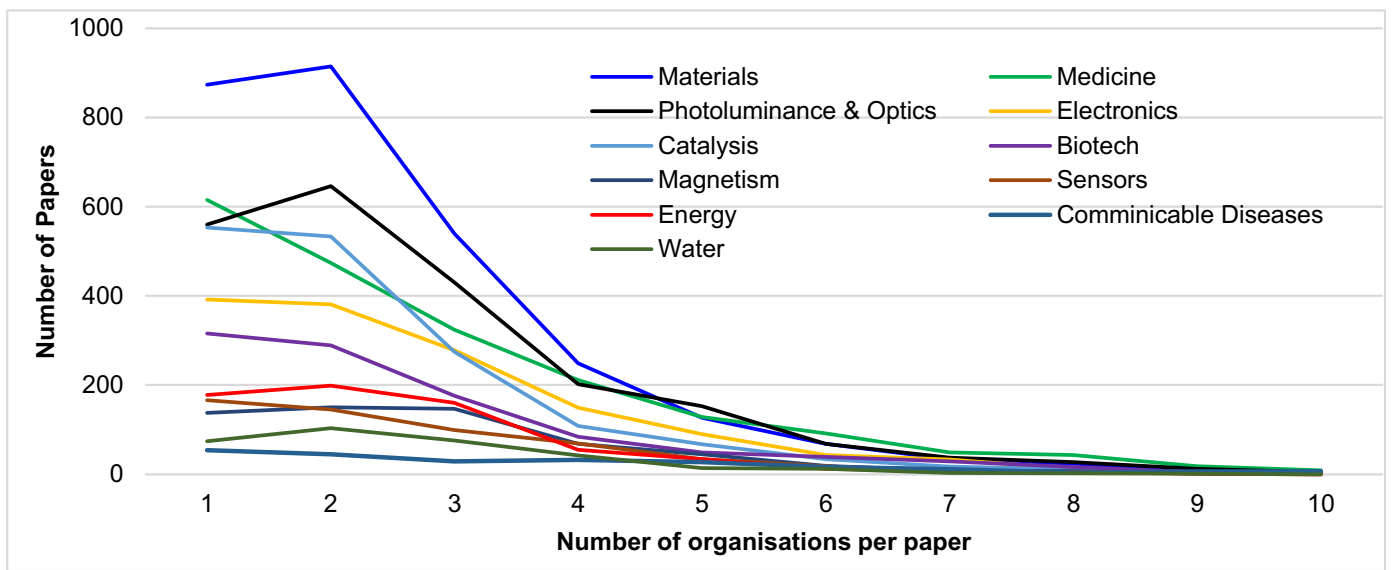

Fig. 4 Level of organisational collaboration per research area 
Table 12 Degree of collaboration for research areas

\begin{tabular}{llllll}
\hline Research area & $\begin{array}{l}\text { Total number } \\
\text { of papers }\end{array}$ & $\begin{array}{l}\text { Single researcher } \\
\text { authored papers }\end{array}$ & $\begin{array}{l}\text { Single organisation } \\
\text { authored papers }\end{array}$ & $\begin{array}{l}\text { Researcher degree } \\
\text { of collaboration }\end{array}$ & $\begin{array}{l}\text { Organisational } \\
\text { degree of collaboration }\end{array}$ \\
\hline Materials & 2845 & 57 & 874 & 0.98 & 0.69 \\
Photoluminance \& Optics & 2172 & 38 & 560 & 0.98 & 0.74 \\
Medicine & 2008 & 53 & 615 & 0.97 & 0.69 \\
Catalysis & 1606 & 16 & 553 & 0.99 & 0.66 \\
Electronics & 1390 & 74 & 392 & 0.95 & 0.72 \\
Biotechnology & 1021 & 41 & 316 & 0.96 & 0.69 \\
Energy & 655 & 12 & 178 & 0.98 & 0.96 \\
Magnetism & 587 & 24 & 138 & 0.96 & 0.76 \\
Sensors & 553 & 6 & 166 & 0.99 & 0.99 \\
Water & 328 & 3 & 74 & 0.99 & 0.77 \\
Communicable Diseases & 243 & 6 & 54 & 0.78 \\
\hline
\end{tabular}

- $\quad \mathrm{NS}=$ number of single-authored papers

Collaboration in for South Africa's research areas was evaluated using co-authorship by authors and coauthorship by organisations. Figure 3 shows the level of co-authorship for the research areas. Only $2 \%$ of papers are single-author papers, the majority are by either 3 or 4 authors. The co-authorship distribution is bimodal; there are $19 \%$ papers with three authors and another $19 \%$ with four authors.

The degree of collaboration was further investigated using organisational co-authorship, as shown in Fig. 4 below. The level of organisational collaboration is lower than researcher collaboration. Most papers, 30\%, are authored by researchers from a single organisation. The second-highest level is two organisations, and then, the collaboration falls exponentially such that at 10 organisations, there is only $0.05 \%$ of organisational co-authorship.

Table 12 below shows the level of collaboration, according to research areas and organisations. There is a high degree of collaboration between researchers varying from 0.95 to 0.99 . However, there is a lower degree of collaboration among organisations varying between 0.69 and 0.78 .

South Africa research area citation rates

The citation rates of the research areas were examined using citations per paper and relative citation rates. The average citation per nano-article for South Africa is 9.08 citations per paper (StatsNano 2020). This number was used to calculate the research area citation rate. Table 13

Table 13 Research area citations 2000-2019

\begin{tabular}{|c|c|c|c|c|}
\hline Research area & Total citations & Number of papers & Citation per paper & Relative citation rate \\
\hline Electronics & 18,549 & 1390 & 13.3 & 1.47 \\
\hline Energy & 10,449 & 655 & 16.0 & 1.76 \\
\hline Photoluminance \& Optics & 36,209 & 2172 & 16.7 & 1.84 \\
\hline Magnetism & 10,313 & 587 & 17.6 & 1.93 \\
\hline Sensors & 9964 & 553 & 18.0 & 1.98 \\
\hline Materials & 52,593 & 2845 & 18.5 & 2.04 \\
\hline Catalysis & 33,952 & 1606 & 21.1 & 2.33 \\
\hline Medicine & 42,458 & 2008 & 21.1 & 2.33 \\
\hline Water & 7013 & 328 & 21.4 & 2.35 \\
\hline Biotech & 24,644 & 1021 & 24.1 & 2.66 \\
\hline Communicable Diseases & 8203 & 243 & 33.8 & 3.72 \\
\hline
\end{tabular}




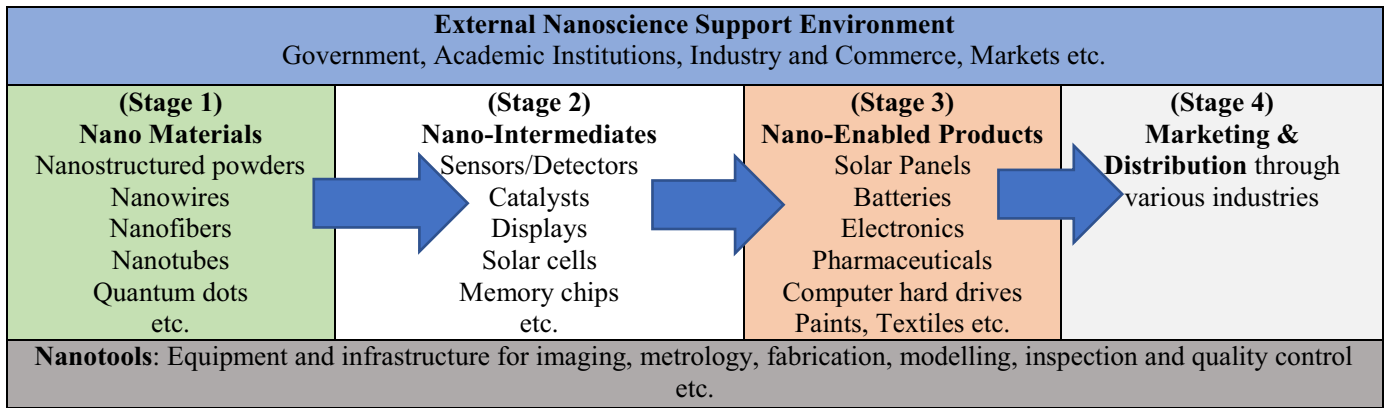

Fig. 5 Nanotechnology value chain

shows that electronics has the lowest citation rate at 13.3 citations per paper and communicable diseases have the highest citation rate of 33.8 citations per paper.

The nanotechnology value chain analysis for South Africa research areas

The transformation of nanotechnology inventions from ideation to commercialisation occurs in three main steps known as the nanotechnology value chain (Gkanas et al. 2013; Shapira et al. 2011; Wang and Guan 2012). Figure 5 below shows the key stages of the nanotechnology value chain. The nanotechnology value chain starts from nanomaterials, then moves to nano-intermediaries and finally nano-enabled products. The value chain enables decision-makers and foresight planners to classify nanotechnology research according to the point at which they contribute to products development and commercialisation. Basic research contributes more to the nano-materials, while applied research contributes more to nano- intermediates. The nano-intermediates are semifinished products with nanoscale features such as sensors and detectors. Innovation and commercialisation are more visible through nanoenabled products. In the nano-enabled product stage, there is hybridisation/incorporation of nanointermediates into existing industries; for example, there will be solar cells being incorporated into energy products or electronics, resulting in nano-energy and nanoelectronics, respectively.

South African publications were analysed and categorised according to the nanotechnology value chain. Figure 6 shows that before 2013, the majority of papers produced (49\%) were in nano-materials; however, as of December 2019, more papers produced are now in the nano-intermediaries stage (52\%). The number of papers reporting on nano-enabled products also went up by $1 \%$, from $3 \%$ to $4 \%$, and this shows that the nanotechnology research system is evolving and moving towards the more innovative and commercialisationoriented stages of the value chain.

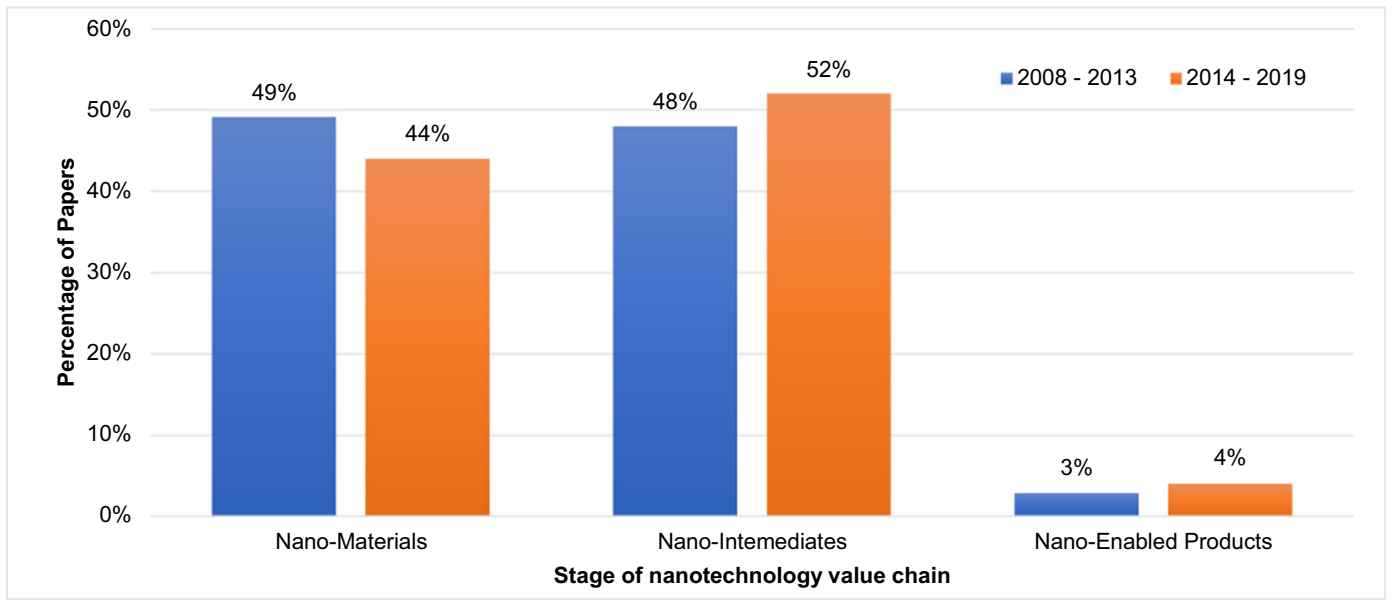

Fig. 6 Publications classified according to the nanotechnology value chain for two periods 


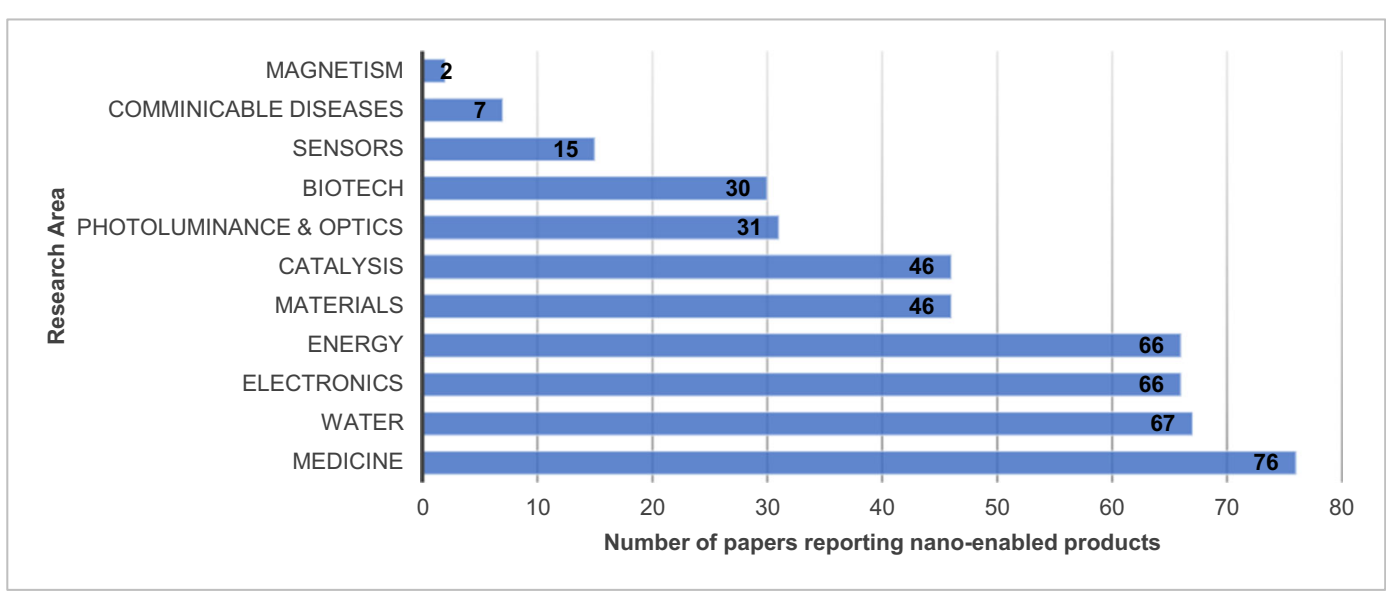

Fig. 7 Number of papers reporting nano-enabled products per research area

The ultimate goal of science and technology is to develop nano-enabled products that can be used to address socio-economic goals and improve the quality of life. Figure 7 below shows the number of publications reporting on nano-enabled products per research area. Medicine has the highest number of papers at 76 , followed by water, electronics and energy.

South Africa's selected nano-enabled product papers compared with BRICS countries

South African papers reporting on nano-enabled products were compared with BRICS countries using the last 5000 publications up to December 2019. Figure 8 below shows the comparison of publications in medicine, electronics and energy.
South Africa and Russia produced the least publications on nano-enabled products. China has the highest number of publications related to nanoenabled products, followed by India. The results seem to confirm the widely held view that China is the leading producer and exporter of electronics (Gangnes and Van Assche 2008; Investopedia 2019).

\section{Conclusions}

In the last 20 years spanning from the year 2000 to 2019 , nanotechnology in South Africa has grown exponentially, publications per year increased from 68 in 2000 to 1672 in 2019 , an increase of $2458 \%$. Nanotechnology

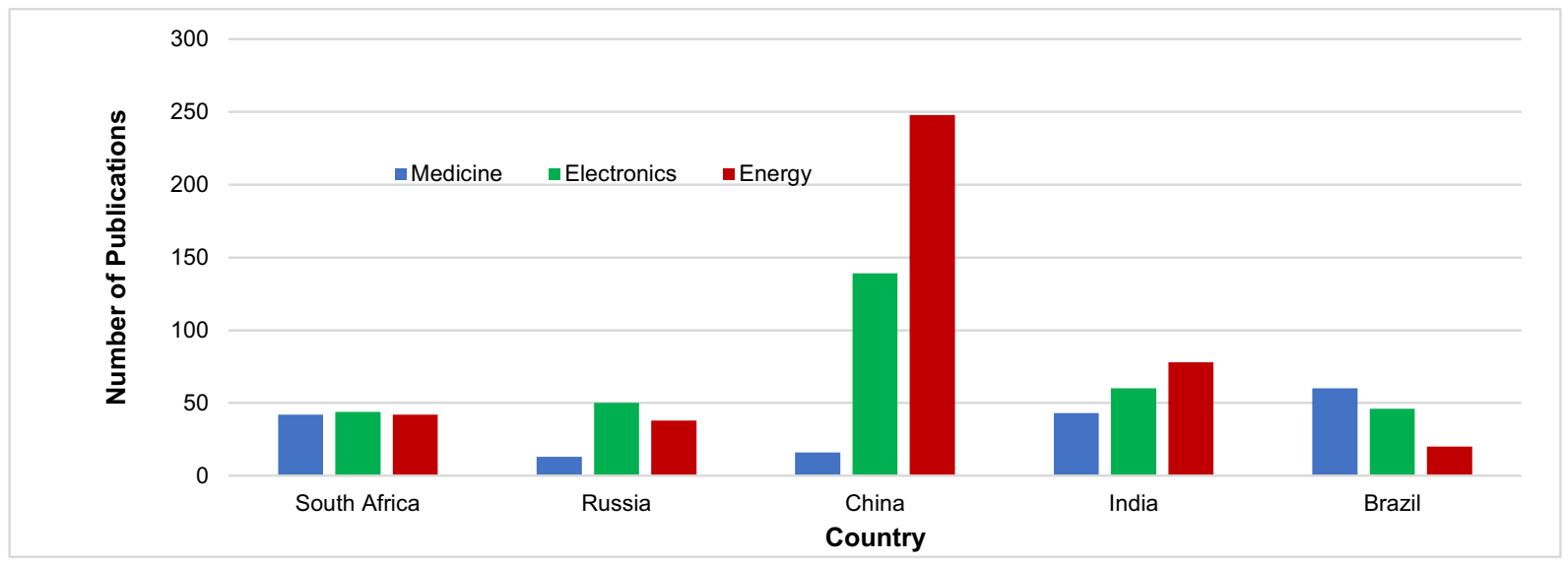

Fig. 8 South Africa publications reporting on nano-enabled products relative to BRICS countries 
research also grew at a faster rate as compared with overall publication growth, which experienced 508\% growth over the same period. The total share of nanotechnology publications increased from $1.4 \%$ in 2000 to $6.6 \%$ in 2019 , thus an average of $0.52 \%$ increase per year. However, when compared with BRICS countries, South Africa has the lowest nanotechnology productivity with an activity index of 0.68 for the last 20 years. China is the most productive with an activity index of 2 . This picture is not very different when the recent past year 2019 is considered. From a foresight perspective, South Africa can benefit from collaborating with the more productive BRICS countries, benchmark their strategies and policies to help South Africa improve and achieve comparable nanotechnology activity levels.

The top four publishing subject areas, namely chemistry, material science, physics and engineering, together account for $93.05 \%$ in the last 20 years and $95.34 \%$ in 2019 of nanotechnology publications for South Africa. When the year 2019 is considered separately, the emergence of computer science as one of the top 20 subjects publishing in nanotechnology suggests a convergence of nanotechnology and computing science, or drive from artificial intelligence (AI) system design and the drive towards the 4th Industrial Revolution (4IR). However, additional investigations need to be done to ascertain the existence and extent of the fusion of nanotechnology, biotechnology, information technology, cognitive sciences and artificial intelligence (NBICA) in South Africa.

Universities are the most prominent publishers of nanotechnology research in South Africa, followed by national research facilities. In the last 20 years, the most prolific publisher among universities is the University of Johannesburg, contributing 14\%, while the most prolific national facility was the CSIR contributing $9 \%$. When the 2019 1-year snapshot is considered, the top publishers remained mostly unchanged, with the University of Johannesburg still at the top. However, the University of South Africa, iThembaLABS and Tshwane University of Technology show that they have increased their nanotechnology activity, producing more relative publications. There was minimal participation of the private sector in nanotechnology research, and this will negatively impact the innovation and commercialisation of nanotechnology research. From a foresight perspective, this indicates that there is a need to engage more private sector to be involved in nanotechnology research through programmes such as joint research with academic institutions.
The publication output is heavily skewed to the most prolific authors such that the top ten authors jointly contributed $21.35 \%$ in the last 20 years, and in 2019 alone, the top 10 authors contributed $20.39 \%$ of publications. This result is inline with Lotka's law (Phillips 2013) which state that the distributions of science and technology publications are highly skewed such that the leaders tend to be extremely prolific, while the rest occur in "ones and twos." When the year 2019 is considered separately, there is the emergence of new top authors that suggested that new researchers/authors are coming into the system mixed with experienced authors who have been there for years. This mixture is essential in foresight planning because it demonstrates continuity, and it suggests some form of succession planning taking place within the nanotechnology system of South Africa.

International and local collaborations are important for science and technology development. Internationally, India is the largest collaborating partner for South Africa, co-authoring $11 \%$ of publications, while in Africa, Nigeria is the most significant collaborator. The relative percentage of co-authored papers between South Africa and the BRICS countries increased in 2019 compared with the last 20 years; for example, in 2019, Russia now appears on the top 20 collaborating countries at number 17, but it did not appear on the top 20 list for the last 20 years; this can be attributed to efforts made under the BRICS collaboration. There is a high degree of collaboration between researchers varying from 0.95 to 0.99 , and 3 or 4 authors write the majority of papers. However, there is a lower degree of collaboration among organisations varying between 0.69 to 0.78 , and the majority of papers are authored by researchers from a one or two institutions.

The strategic nanotech research areas with a socioeconomic benefit for South Africa were identified to include materials science, photoluminance and optics, medicine, catalysis, electronics, energy, biotech, magnetism, sensors, water and communicable diseases. The top publishers per research area were identified; for example, in material science, it is Ray Suprakas, in medicine it is Nyokong Tebello, in electronics and energy it is Maaza Malik, in water it is Mamba Bhekie, in photoluminance and optics it is Swart Hendrik. Top publishing institutions per research area were also identified; for example, in nanomedicine, it is the University of KwaZulu Natal, University of Witwatersrand and University of Cape Town. University of the Free state 
is the leading publisher in photoluminance and optics, and the University of Pretoria is the leading institution for nanoelectronics. India is the top collaborating country in seven research areas; however, for medicine and communicable diseases, the top collaborating country is the USA, for energy China, and for water Belgium.

Nanotechnology companies tend to cluster into some regions instead of being evenly distributed in a country; hence, regional clusters for the different research areas were also examined using the country's economic hubs. The results indicate that provinces are strong in different sub-fields of nanotechnology. For example, if one needs to develop a business in photoluminance and optics, they need to locate either in Pretoria or the Free State, for nanomedicine, they need to be in Western Cape or Johannesburg, and communicable diseases research in Western Cape or KwaZulu Natal region.

The quality of papers was evaluated using citation rates, electronics has the lowest citation rate at 13.3 citations per paper, and communicable diseases have the highest citation rate of 33.8 citations per paper. The level of innovation for the research areas was evaluated using the nanotechnology value chain, and medicine has the highest number of papers reporting on nano-enabled products followed by water, electronics and energy. When South Africa is compared with the BRICS countries using the last 5000 publications of 2019, China has the highest number of publications related to nano-enabled products, followed by India. The results seem to confirm the widely held view that China is the leading producer and exporter of electronics (Gangnes and Van Assche 2008; Intrepidsourcing 2018; Investopedia 2019). South Africa needs to benchmark with these other countries to increase its level of innovation and nano-enabled product output.

In conclusion, this research has presented an environmental scan of nanotechnology in South Africa for the past 20 years, and also evaluated possible socioeconomic relevant sectors arising from this information. Foresight planners, investors, government policymakers and R\&D managers can use the information to evaluate the possible nanotechnology research areas in which they can invest in South Africa.

\section{Limitations of the study}

While scientometric indicators present quantitative and evidence-based indicators for foresight studies, they suffer from several limitations. Scientometric indicators are lagging indicators because it takes an article at least a year or more to be published, while patents can take several years to be granted. Tech-mining can answer questions on who, what, where and when. However, the answers to questions regarding the process of how, and the reason why almost always require expert opinion to answer them (Porter and Cunningham 2005). Not all research is published or patented, for example, an academic scientist or engineer is 45 times more likely to publish his/her research than an industrial counterpart (Porter and Cunningham 2005). Scientometric indicators are at best proxies of more 'intangible' dimensions, for example, scientometrics tend to reduce constructs like "research quality" to "citation impact" and "research collaboration" to "co-authorship", these are complex aspects. Thus, current bibliometric methods are simply inadequate to measure such properties adequately and need to be augmented by other evaluation methods.

\section{Recommendations}

As an emerging research area, the system of classifying nanotechnology papers into economic sectors such as nanomedicine, nanoenergy, nanoagriculture, nanoelectronics and so on is not yet well established. Secondly, most researchers do not file patents; hence, it is sometimes difficult to evaluate the state of innovation using patents data because the data will be little. For example, between 2000 and 2019, South Africa produced only 43 patents on the European Patents Office (EPO) database versus a massive 11,625 publications on WoS core collection. Hence, one way to evaluate innovation will be to use the nanotechnology value chain classification of papers. Unfortunately, the system for classifying publications according to the nanotechnology value chain is also not well developed. Thus, there is a need to develop further and refine nanotechnology research area systems classification systems that can be used to evaluate research areas for foresight and research portfolio management purposes.

When the year 2019 is considered, the emergence of computer science as one of the top 20 subjects publishing in nanotechnology suggests that nanotechnology convergence (Roco 2020) is happening the country. In addition, it was observed that there is a high degree of author/researcher collaboration within nanoscience in South Africa; this may also suggest convergence of 
disciplines with nanoscience research, but we are not sure at this stage, one needs to investigate if these authors are collaborating across disciplines or within disciplines. Hence, additional investigations need to be done to ascertain the existence and the extent of the fusion of nanotechnology, biotechnology, information technology, cognitive sciences and artificial intelligence (NBICA) within the South African nanoscience landscape. There is also a need to investigate and understand if convergence is in the confluence phase, for example, just across disciplines and subjects, or it has advanced to the integration phase where frameworks and systems are now developed to solve problems that individual capabilities/disciplines cannot solve on their own (Roco 2020). Such an investigation will enable foresight planners to understand how nanotechnology convergence is evolving and how the future may look for the country's national innovation system.

Acknowledgements Vantage Point Student Edition Technology Mining Software.

\section{Declarations}

Financial interest Author Brian Masara received Doctor of Business Leadership (DBL) bursary funding from the University of South Africa (UNISA) for this research.

Conflict of interest The authors declare that they have no conflict of interest.

\section{References}

Ali A, Sinha K (2014) Exploring the opportunities and challenges in nanotechnology innovation in India. J Soc Sci Policy Implic 2:227-251. https://doi.org/10.15640/jsspi

Arora SK, Porter AL, Youtie J, Shapira P (2013) Capturing new developments in an emerging technology: an updated search strategy for identifying nanotechnology research outputs. Scientometrics 95:351-370. https://doi.org/10.1007/s11192012-0903-6

Banin U, Waiskopf N, Hammarström L et al (2020) Nanotechnology for catalysis and solar energy conversion. Nanotechnology 32:042003

Battard N (2012) Convergence and multidisciplinarity in nanotechnology: Laboratories as technological hubs. Technovation 32:234-244. https://doi.org/10.1016/j. technovation.2011.09.001

Connell J, Edgar GC, Olex B, Scholl R, Shulman T, Tietjen R (2001) Troubling successes and good failures: successful new product development requires five critical factors. Eng Manag J 13:3539. https://doi.org/10.1080/10429247.2001.11415136

de Miranda SM, Coelho GM, dos Santos DM, Filho LF (2006) Text mining as a valuable tool in foresight exercises: a study on nanotechnology. Technol Forecast Soc Change 73:10131027. https://doi.org/10.1016/j.techfore.2006.05.020

De Sio L, Ding B, Focsan M et al (2021) Personalized reusable face masks with smart nano-assisted destruction of pathogens for COVID-19: a visionary road. Chem - A Eur J 27: chem.202004875. https://doi.org/10.1002/chem.202004875

DST (2005) The National Nanotechnology Strategy. In: Repub. South Africa, Dep. Sci. Technol. https://www.gov. $\mathrm{za} / \mathrm{sites} / \mathrm{default} /$ files/gcis_document/201409 /dstnanotech180120060.pdf. Accessed 13 Dec 2020

DST (2007) INNOVATION TOWARDS A KNOWLEDGEBASED ECONOMY Ten-Year Plan for South Africa. In: Repub. South Africa, Dep. Sci. Technol. https://www.dst. gov.za/index.php/resource-center/strategies-and-reports/143the-ten-year-plan-for-science-and-technology. Accessed 15 May 2020

Fiedler M, Welpe IM (2011) Commercialisation of technology innovations : an empirical study on the influence of clusters and innovation networks. Int J Technol Manag 54:410-437. https://doi.org/10.1504/IJTM.2011.041582

Firat AK, Woon WL, Madnick S (2008) Technological forecasting - a review. Cambridge 02142

Gangnes B, Van Assche A Van (2008) China and the Future of Asian Electronics Trade. SSRN Electron J https://doi. org/10.2139/ssrn.1330872

Gkanas EI, MagkouKriticou V, Makridis SS et al (2013) Nanotechnology and innovation, recent status and the strategic implication for the formation of high tech clusters in Greece, in between a global economic crisis. Int J Technol Innov Res 2

Grassian VH, Haes AJ, Mudunkotuwa IA, Demokritou P, Kane AB, Murphy CJ, Hutchison JE, Isaacs JA, Jun YS, Karn B, Khondaker SI, Larsen SC, Lau BLT, Pettibone JM, Sadik OA, Saleh NB, Teague C (2016) NanoEHS - defining fundamental science needs: no easy feat when the simple itself is complex. Environ Sci Nano 3:15-27. https://doi.org/10.1039 /c5en00112a

Hideg E (2007) Theory and practice in the field of foresight. Foresight 9:36-46. https://doi.org/10.1108/14636680710837299

Hirsch JE (2005) An index to quantify an individual's scientific research output. Proc Natl Acad Sci U S A 102:1656916572. https://doi.org/10.1073/pnas.0507655102

Hullman A, Meyer M (2003) Publications and patents in nanotechnology - an overview of previous studies and the state of the art. Scientometrics 58:507-527. https://doi. org/10.1023/B:SCIE.0000006877.45467.a7

Intrepidsourcing (2018) Consumer Electronics Industry Report for China \& Asia: an overview | Intrepid Sourcing. https://intrepidsourcing.com/industry-reports/consumerelectronics-industry-report/. Accessed 21 Nov 2020

Investopedia (2019) Which countries are most important in electronics? https://www.investopedia.com/ask/answers/042915 /what-countries-contribute-largest-weight-globalelectronics-sector.asp. Accessed 21 Nov 2020

Islam N, Miyazaki K (2009) Nanotechnology innovation system: understanding hidden dynamics of nanoscience fusion 
trajectories. Technol Forecast Soc Change 76:128-140. https://doi.org/10.1016/j.techfore.2008.03.021

Islam N, Miyazaki K (2010) An empirical analysis of nanotechnology research domains. Technovation 30:229-237. https://doi.org/10.1016/j.technovation.2009.10.002

Jacobs D (2010) Demystification of Bibliometrics, Scientometrics, Informetrics and Webometrics. In: 11th DIS Annual Conference. pp 1-19

Kalle A, Rafael A (2015) Theory of and within foresight - "What does a theory of foresight even mean ?". Technol Forecast Soc Change 9:191-201. https://doi.org/10.1016/j. techfore.2015.03.003

Karpagam R, Gopalakrishnan S, Natarajan M, Ramesh Babu B (2011) Mapping of nanoscience and nanotechnology research in India: a scientometric analysis, 1990-2009. Scientometrics 89: 501-522. https://doi.org/10.1007/s11192-011-0477-8

Lee W (2008) How to identify emerging research fields using scientometrics : an example in the field of Information Security. Scientometrics 76:503-525. https://doi. org/10.1007/s11192-007-1898-2

Lee Y-G, Song Y-I (2007) Selecting the key research areas in nanotechnology field using technology cluster analysis: A case study based on National R\&amp;D Programs in South Korea. Technovation 27:57-64. https://doi.org/10.1016/j. technovation.2006.04.003

Leydesdorff L, Milojevic S (2012) Scientometrics 1. arXiv Prepr arXiv 1208.4566

Linton JD, Walsh ST (2008) A theory of innovation for processbased innovations such as nanotechnology. Technol Forecast Soc Change 75:583-594. https://doi.org/10.1016/j. techfore.2007.02.005

Makhoba X, Pouris A (2017) Bibliometric analysis of the development of nanoscience research in South Africa. S Afr J Sci 113:1-9. https://doi.org/10.17159/sajs.2017/20160381

Mamba BB, Krause RW, Malefetse TJ, Nxumalo EN (2007) Monofunctionalized cyclodextrin polymers for the removal of organic pollutants from water. Environ Chem Lett 5:7984. https://doi.org/10.1007/s10311-006-0082-x

Mangematin V, Walsh S (2012) The future of nanotechnologies. Technovation 32:157-160. https://doi.org/10.1016/j. technovation.2012.01.003

Marinova D, McAleer M (2002) Nanotechnology strength indicators: international rankings based on US patents. Nanotechnology 13:R1-R7. https://doi.org/10.1088/0957$4484 / 14 / 1 / 201$

Marshal A (1920) Principles of Economics, 8th edn. McMillian, London

Martin BR (1995) Foresight in Science and Technology. Tech Anal Strat Manag 7:139-168. https://doi.org/10.1080 /09537329508524202

Martin BR (2001) Technology foresight in a rapidly globalizing economy. In: Reginal Conference on Technology Foresight. pp 1-19

Mikova N, Sokolova A (2014) Comparing information sources for identifying technology trends. In: 5th International Conference on Future-Oriented Technology Analysis (FTA) - Engage today to shape tomorrow. Brussels [online], https://ec.europa.eu/jrc/sites/jrcsh/files/fta2014-t3 practice_195.pdf, pp 1-12

Miyazaki K, Islam N (2007) Nanotechnology systems of innovation-An analysis of industry and academia research activities. Technovation 27:661-675. https://doi.org/10.1016 /j.technovation.2007.05.009

Mwabi JK, Adeyemo FE, Mahlangu TO et al (2011) Household water treatment systems: a solution to the production of safe drinking water by the low-income communities of Southern Africa. Phys Chem Earth 36:1120-1128. https://doi. org/10.1016/j.pce.2011.07.078

NPC (2011) Nationational Development Plan: Vision for 2030. In: Repub. South Africa, Natl. Plan. Comm. https://www. nationalplanningcommission.org.za/National_ Development_Plan. Accessed 12 Mar 2021

NSF (2014) Market report on emerging nanotechnology. http://www.nsf.gov/news/news_summ.jsp?cntn_id=130586 \&org=NSF\& from=news

Peneder M (1997) Creating a coherent design for cluster analysis and related policies: the Austrian Tip Experience. In: OECD Workshop on Cluster Analysis and Cluster Based Policies. WIFO Studies, WIFO, number 2861:1-22

Phillips JG (2013) Technology foresight for small-to mediumsized enterprises. Univ Alberta, Mech Eng. https://doi. org/10.7939/R3GH9BJ22

Popper R (2008) How are foresight methods selected? Foresight 10:62-89. https://doi.org/10.1108/14636680810918586

Porter AL, Cunningham SW (2005) Tech mining: exploiting new technologies for competitive advantage. Wiley-Interscience, Hoboken

Porter ME, Stern S (2001) Innovation : location matters. In: MIT Sloan Manag. Rev. https://sloanreview.mit. edu/article/innovation-location-matters/. Accessed 20 May 2020

Porter AL, Youtie J, Shapira P, Schoeneck DJ (2008) Refining search terms for nanotechnology. J Nanopart Res 10:715728. https://doi.org/10.1007/s11051-007-9266-y

Pouris A (2007) Nanoscale research in South Africa: a mapping exercise based on scientometrics. Scientometrics 70:541553. https://doi.org/10.1007/s11192-007-0301-7

Robinson DKR, Rip A, Magematin V (2007) Technological agglomeration and the emergence of clusters and networks in nanotechnology. Res Policy 36:871-879. https://doi. org/10.1016/j.respol.2007.02.003

Roco MC (2017) Overview: affirmation of nanotechnology between 2000 and 2030. In: Nanotechnology commercialization: manufacturing processes and products. Wiley, Hoboken, pp 1-23

Roco MC (2020) Principles of convergence in nature and society and their application: from nanoscale, digits, and logic steps to global progress. J Nanopart Res 22:321. https://doi. org/10.1007/s11051-020-05032-0

Roco MC, Bainbridge WS (2002) Converging technologies for improving human performance: Integrating from the nanoscale. J Nanopart Res 4:281-295. https://doi.org/10.1023 /A:1021152023349

Roco MC, Mirkin CA, Hersam MC (2011) Nanotechnology research directions for societal needs in 2020: Summary of international study. J Nanopart Res 13:897-919. https://doi. org/10.1007/s11051-011-0275-5

Rousseau R (2018) The F-measure for Research Priority. J Data Inf Sci 3:1-18. https://doi.org/10.2478/jdis-2018-0001

Salerno M, Landoni P, Verganti R (2008) Designing foresight studies for Nanoscience and Nanotechnology (NST) future developments. Technol Forecast Soc Change 75:1202-1223. https://doi.org/10.1016/j.techfore.2007.11.011 
Santo MDM, Coelho GM, Maria D, Filho LF (2006) Text mining as a valuable tool in foresight exercises : a study on nanotechnology. 73:1013-1027. https://doi.org/10.1016/j. techfore.2006.05.020

Schummer J (2004) Multidisciplinarity, Interdisciplinarity, and Research Collaboration in Nanoscience and Nanotechnology. Scientometrics 59:425-465. https://doi.org/10.1023 /B:SCIE.0000018542.71314.38

Shapira P, Youtie J, Kay L (2011) National innovation systems and the globalization of nanotechnology innovation. $\mathrm{J}$ Technol Transf 36:587-604. https://doi.org/10.1007 /s10961-011-9212-0

Shen Y-C, Chang S-H, Lin GTR, Yu H-C (2010) A hybrid selection model for emerging technology. Technol Forecast Soc Change 77:151-166. https://doi.org/10.1016/j. techfore.2009.05.001

StatsNano (2020) South Africa Nanoscience Indicators. In: StatsNano Website. https://statnano.com/country/southafrica. Accessed 20 Jun 2020

Subramanyam K (1983) Bibliometric studies of research collaboration: A review. J Inf Sci 6:33-38. https://doi.org/10.1177 $/ 016555158300600105$
Tanaka M (2013) Toward a proposed ontology for nanoscience. In: Proceedings of the Annual Conference of CAIS/Actes du congrès annuel de l'ACSI. Brookville, New York

Torkkeli M, Tuominen M (2001) The contribution of technology selection to core competencies. Int J Prod Econ 77:271-284. https://doi.org/10.1016/S0925-5273(01)00227-4

Tuncel CO (2015) Neo-Schumpeterian long wave theory and nanotechnology: assessing the future of manufacturing industry. J Econ Dev Stud 3:57-81. https://doi.org/10.15640/jeds.v3n1a5

Von Wright GH (2009) Determinism and knowledge of the future. Futura 1:15-27

Wang G, Guan J (2012) Value chain of nanotechnology: a comparative study of some major players. J Nanopart Res 14:114. https://doi.org/10.1007/s11051-011-0702-7

Publisher's note Springer Nature remains neutral with regard to jurisdictional claims in published maps and institutional affiliations. 